\title{
3
}

\section{The Three Institutions, Their Roles and the Environment}

The three institutions studied were all founded to deal with economic issues and to promote economic growth and stability. While this raison d'être and a broadly economic worldview are shared characteristics among them, they differ in terms of governance functions, organisational set-up, worldview, membership and decisionmaking procedures, interaction with other institutions, environmental track record and in the case of the OECD and the IMF also the autonomy of the International Organisation (IO) bureaucracy. The G20 is an informal forum for the most powerful state leaders and finance ministers in the world, the OECD is a key producer of (often quantified and economic) knowledge about all sorts of policy issues and the IMF is one of the most powerful IOs in the world as regards shaping national policy. To analyse economisation in the shape of how the institutions have addressed fossil fuel subsidies and climate finance, it is necessary to understand their background and how they align in terms of these factors. The factors may explain differences and similarities in their economisation of the two issues, as explored in the subsequent parts of the book. This chapter describes the three institutions individually, starting with the G20, followed by the OECD and the IMF. For each institution, the chapter outlines their history, governance functions, organisational set-up, worldview, membership and decision-making procedures, interaction with other institutions, environmental track record and for the OECD and the IMF also the autonomy of bureaucracies.

\subsection{The G20}

The G20 was established in 1999 primarily to deal with economic issues. Following the 1997-8 Asian financial crisis, several countries wanted a forum that was smaller, more informal and flexible than the UN institutions, while it at the same time included the larger emerging economies, unlike the Group of Seven $(\mathrm{G} 7)^{1}$.

\footnotetext{
${ }^{1}$ The United States, Japan, Germany, the United Kingdom, France, Italy and Canada.
} 
Initially, the G20 was a forum of finance ministers and central bank governors, but since 2008 the state leaders have met annually and the G20 process has been driven by them rather than the finance ministers and central bank governors. Its membership consists of nineteen of the thirty-three largest national economies (Argentina, Australia, Brazil, Canada, China, France, Germany, India, Indonesia, Italy, Japan, Mexico, Russia, Saudi Arabia, South Africa, South Korea, Turkey, United Kingdom, United States), and the European Union. ${ }^{2}$ Permanent guest invitees are the IMF, the OECD, the Financial Stability Board, the International Labour Organization, the UN, the World Bank Group, the World Trade Organization, the African Union, the Asia-Pacific Economic Cooperation (APEC), the New Partnership for Africa's Development (the last three represented by the country holding the annually rotating presidency) and Spain. Other countries have been invited as non-permanent guests.

\subsubsection{Governance Functions}

The G20 is a forum for discussions on all sorts of international issues from violent conflicts to sustainable development, yet its original raison d'être - coordination of economic policy - is visible in its prioritisation of issues and their economic impact. During the first phase of the economic and financial crisis in 2008-9, the G20 emerged as the global forum for the coordination of economic policy (Barbier, 2010; Van de Graaf and Westphal, 2011). The G20 formal output is mainly declaratory and to some degree regulatory, consisting of joint statements, commitments, communiqués and reports. The statements and commitments may commit member states to particular actions (e.g. reforming fossil fuel subsidies), but do not contain legal obligations or sanctions in case of non-adherence. The G20 is an informal institution characterised by face-to-face interaction in small in-camera groups (Kim and Chung, 2012). Consequently, it also provides important informal output in the shape of workshops and ministerial meetings constituting venues for disseminating knowledge and socialisation into norms (on in-camera settings being favourable to socialisation, see Checkel, 2005).

More generally, while the G20 functioned as a crisis committee during the 2008-9 economic and financial crisis, coordinating national responses to the crisis, it has subsequently developed into a global 'steering committee' (Cooper, 2010; Crump and Downie, 2018; Drezner, 2014; Held and Young, 2013). A steering committee can be understood as 'a diplomatic device to encourage consensus between the biggest countries on major transnational issues' (Van de Graaf and Westphal 2011: 20). As such, the G20 is used for steering and coordinating

\footnotetext{
${ }^{2}$ The G20 members do not correspond exactly to the twenty largest economies in the world measured in terms of GDP.
} 
government policies through the commitments they adopt. While the steering role predominantly focuses on economic governance, particularly preventing excessive problems of global capitalism while preserving this system (Cooper, 2010) and its legitimacy (Slaughter, 2015), issues such as energy (Downie, 2015; Van de Graaf and Westphal, 2011) and climate change (Kim and Chung, 2012) have also been subject to steering. This steering role is more far-reaching and has a more long-term focus than 'just' being a global crisis committee. Finally, the role of the G20 is also described in terms of its ability to address issues characterised by deadlock within larger multilateral forums, particularly within the UN system, owing to its smaller and more informal setting (Cooper and Thakur, 2013; Widerberg and Stenson, 2013).

\subsubsection{Organisational Set-up}

The G20 does not have its own secretariat but relies on the state holding the annually rotating Presidency. The current Presidency works with the previous and upcoming Presidencies in the so-called G20 troika to ensure continuity, but only the current Presidency decides on the G20 agenda. The Presidency's influence over the agenda is most pronounced in its authority to decide whether papers from the different tracks preparing the G20 state leaders' summit make it to the agenda of the summit or not (Crump and Downie, 2018; Slaughter, 2017). Yet, the power of the Presidency over the agenda is not complete; for instance, the 2014 Australian Presidency was not able to keep climate change off the G20 agenda when most other G20 members wanted to address it (Pickering and Mitchell, 2017). The state leaders' summit is the most authoritative body within the G20 and is prepared through two tracks: the finance track involving finance ministry (and to some degree also central bank) representatives and the Sherpa track involving senior advisors to the state leaders, the so-called Sherpas. These two tracks are constituted by meetings between on the one hand finance ministers and central bank governors and on the other hand Sherpas, as well as a range of expert working groups that prepare draft decisions and papers for the finance ministers (and central bank governors) and the Sherpas respectively. These expert groups are not permanent in the way OECD expert groups are, but typically last for a few Presidencies until they are no longer included in an incoming Presidency's priorities. Generally speaking, the finance ministers and central bank governors deal with issues of economic relevance and the Sherpas with other issues. Besides these two tracks, other ministries such as agriculture, energy health and trade ministers also meet from time to time, but such meetings depend on individual decisions (mainly driven by the Presidency) and are not institutionalised in the way the finance ministers/ 
central bank governors and Sherpa tracks are. Conclusions from ministerial meetings are notable in their own right beyond shaping state leaders' conclusions, as they define G20 positions on issues that are not deemed sufficiently important to make it onto the limited agenda of the state leaders.

\subsubsection{Worldview}

Although the G20 addresses a range of issues, its original raison d'être of addressing economic issues still shapes its worldview. The G20 has prioritised economic issues and framed other issues in terms of their economic consequences (Slaughter, 2015; Van de Graaf and Westphal, 2011). Thus, the G20 focuses cognitively on the economic aspects of a given policy (for instance the economic consequences of climate change), but also normatively places economic growth and stability above other priorities, except perhaps peace. The criterion for membership of the G20 is also defined in economic terms: as being among the largest economies in the world. The worldview of the G20 is not firmly established in a bureaucracy, but in the meetings (at the state leader, ministerial as well as Sherpa and expert levels) taking place within the G20, including both the ideational environment emerging from regular interaction (Johnston, 2001) and the worldview of the government institutions the participants come from. In this respect it is important that the entire finance ministries track mainly consists of interaction between representatives of finance ministries and to some degree also of central banks. The economic worldview is also enhanced by the predominance of economic institutions among the permanent guests. Yet, there has also been significant contestation within the G20 concerning which economic ideas should prevail, reflecting that it is not a forum based on adherence to particular norms, but rather on process and on delivery in terms of steering (Cooper, 2010: 744). More specifically, emerging economies, particularly the BRICS (Brazil, Russia, India and China) have questioned the norm of free markets and have defended more interventionist approaches to economic policymaking (Chodor, 2017; Cooper and Thakur, 2013).

\subsubsection{Membership and Decision-Making Procedures}

The G20 members are selected primarily on the basis of the size of their economy, although countries such as Spain and the Netherlands are not members despite being among the twenty largest economies, and Argentina and South Africa are members despite being the twenty-first and thirty-third largest economies respectively. This is because regional distribution constitutes a criterion for membership besides economic performance (GLI Team, 2018). The G20 covers a greater share 
of global GDP ( 85 per cent in total) and a more diverse group of countries when compared to the $\mathrm{G} 7$, and is a more 'club-like' institution when compared to the UN (Cooper and Thakur, 2013; Van de Graaf and Westphal, 2011). A key dynamic within the G20 is the relationship between developed and developing countries, an often conflictive relationship that has led to gridlock due to disagreement particularly between the United States and emerging economies (Chodor, 2017). The G20 does not rely on voting but on consensus-based decision-making. There are de facto some member states (especially the United States but also China) that wield more influence than others due to their larger power resources, which can be used to coerce or pay off other member states (Cooper, 2010). Such power relations are more common at the ministerial, Sherpa and state leader levels than within expert groups, which are more technical than the higher-level meetings. Often issues of political contestation are left by the experts to the political actors to solve.

\subsubsection{Interaction with Other Institutions}

The G20 is most closely tied to the G7 but differs in that it includes emerging economies. While the G7 is a more homogeneous group than the G20, making compromise easier, it is also less representative of the world's countries (thus reducing its legitimacy), covers a smaller share of the global economy and is less able to address issues spanning developed and emerging economies (Lesage, 2015). The G20 took over from the G7/8 $8^{3}$ as the preeminent minilateral forum following the 2008-9 economic and financial crisis (Cooper and Thakur, 2013). Occasionally, the homogeneity of the G7/8 means that it may adopt positions or commitments that are not possible to adopt within the G20, for example, on limiting climate change to 2 degrees Celsius (G8, 2009).

The relationship with the UN institutions can be interpreted in diverging ways. Whereas G20 members often justify the forum with reference to its ability to break deadlock within UN negotiations, non-G20 countries and civil society organisations have argued that its lack of representativeness and exclusion of smaller countries greatly reduces its legitimacy (Hajnal, 2015; Slaughter, 2013). Although the G20 covers 66 per cent of the global population, Least Developed Countries are not represented in the G20, and consequently the forum has been criticised for not representing the world's poor.

The OECD, the IMF and the World Bank have more synergistic relationships with the G20. Not only are they permanent guests at G20 meetings, they also provide knowledge input in the shape of reports and papers to the G20 and

\footnotetext{
3 The G7 was known as the G8 from 1997 to 2014, when Russia was a member. It was expelled from the G8 because of its invasion of Ukraine.
} 
participate actively in G20 expert meetings. Likewise, the OECD is also a permanent guest, knowledge provider and active participant in G20 meetings, and often undertake secretariat functions for the G20 (Hajnal, 2019).

\subsubsection{Environmental Track Record}

The G20 started to address environmental issues at the official level in connection with the spring 2009 Summit in London, at which state leaders committed to a 'green recovery' through stimulus packages containing investments in renewable energy, energy efficiency, and so forth (G20 Heads of State and Government, 2009a). Prior to 2009, environmental issues had predominantly been discussed by senior officials. The commitment was a response to calls for a 'green new deal' (Barbier, 2010), amid discussions of a return to Keynesian policies following the economic crisis (Tienhaara, 2016). Nonetheless, the commitment to green recovery was not as detailed as the UK Presidency wanted it to be, and its impact on the member states' economic stimulus packages is debatable (Tienhaara, 2016). The focus on green economic policies continued in the subsequent Korean and French Presidencies in the shape of emphasising green growth, a topic that gradually slipped down the agenda of the 2013 Russian, 2014 Australian and 2015 Turkish Presidencies (Tienhaara, 2016).

Besides green recovery/growth, climate finance and fossil fuel subsidy reform, which the G20 paid particular attention to, the G20 interest in environmental issues has largely been shaped by external events. For instance, the G20 routinely expresses its commitment to the United Nations Framework Convention on Climate Change (UNFCCC) process, and stressed sustainable development in relation to the 2012 Rio+20 Conference on Sustainable Development (G20 Heads of State and Government, 2009b; G20 Heads of State and Government, 2010a, 2010b, 2011, 2012, 2013, 2014, 2015, 2016, 2017, 2018, 2019).

Concerning climate change generally speaking, spectators diverge on the track record and potential of the G20. While some argue that the G20 has led the global effort against climate change to a greater extent than the UNFCCC (Kirton and Kokotsis, 2015) or at least has had the potential to break UNFCCC gridlock (Slaughter, 2017), others have argued that G20 efforts may undermine the UNFCCC process (Eckersley, 2012). Climate change has generally been framed in terms of economic impact, as is evident in the G20 state leaders' declaration at the 2012 Los Cabos Summit (and the 2013 Saint Petersburg Summit) that 'Climate change will continue to have a significant impact on the world economy, and costs will be higher to the extent we delay additional actions' (G20 Heads of State and Government, 2012, 2013, item 71). 
On a related note, energy, including renewable energy and energy efficiency and their link to climate change, has also increasingly been addressed by the G20 (G20 Heads of State and Government, 2011, 2014, 2015, 2016, 2017, 2018, 2019). The notion of the G20 acting as a global steering committee for energy has been popular among some member states and Presidencies, including the 2014 Australian Presidency, although straddling the divide between energy consumers and producers has proven difficult (Downie, 2015; Van de Graaf and Colgan, 2016; Van de Graaf and Westphal, 2011). The G20 has focused on the objectives of promoting 'transparent, well-functioning, reliable energy markets' in terms of inter alia reducing price volatility in energy markets, improving energy efficiency and access to clean technologies, promoting sustainable development and green growth, as well as improving the global governance architecture for energy (Downie, 2015).

\subsection{The OECD}

The OECD was established in 1961 to promote policies improving the economic and social wellbeing of people around the world. Its predecessor was the Organisation for European Economic Co-operation founded in 1948 to manage the Marshall aid distributed to non-Communist European countries. It expanded to include Western countries beyond Europe and North America, and later post-Communist European countries and countries above a certain level of income in Asia and Latin America, specifically Colombia, Israel, South Korea, Mexico and Chile.

\subsubsection{Governance Functions}

The OECD does not possess instruments that can force or incentivise states to change policy in the way for instance the IMF is able to use its conditional lending, but relies on ideational (cognitive and normative) influences (Ruffing, 2010). A key component of such influence is the OECD Secretariat's role as a producer of knowledge and data on all kinds of subjects except security, which is fed into and often produced in collaboration with issue-specific committees and working groups consisting of member state representatives. Thus, the OECD is first and foremost an institution producing knowledge in the shape of data and analysis. The knowledge aims to improve specific policies in its member states and secondarily beyond them. The OECD is one of the most important (the most important in certain policy areas such as education and development) providers of cross-country data. It also provides policy recommendations on the basis of a general analysis of a policy issue (e.g. green investment) as well as of a country-specific analysis of a member state's policies. The $\mathrm{OECD}$ has also been instrumental in developing and promoting important normative 
ideas, notably the polluter pays principle (OECD, 1974). Furthermore, the OECD also acts as an informal venue for interaction and knowledge dissemination among member states, thus providing opportunities for socialisation and learning.

\subsubsection{Organisational Set-up}

The term 'OECD' refers to the entirety of the OECD including the OECD Council, as well as the OECD Secretariat, the international bureaucracy which is an independent actor in its own right. The OECD Council is headed by the Ministerial Council, which is chaired by one of its members on an annually rotating basis, and which meets annually to endorse a set of strategic priorities (Carroll and Kellow, 2011). Ministers from the member states also sometimes meet in sector-specific configurations, for example, meetings of the ministers of agriculture. The OECD Council also consists of the Council of Permanent Representatives (who are Paris-based and meet regularly), sector-specific Committees and their subsidiary bodies. Each Committee has a range of subsidiary Working Parties, which again have subsidiary Working Groups. For instance, the Environment Policy Committee has the Working Party on Climate, Investment and Development as one of its Working Parties. Members of the Committees come from either the member states' permanent representation to the OECD or national ministries based in their respective capitals (e.g. the ministry of the environment in the case of the Environment Policy Committee), whereas members of the working parties and groups tend to be capital-based experts.

The OECD Secretariat is headed by the Secretary-General, currently Angel Gurría, and consists of twelve sector-specific directorates, for example, the Environment Directorate. Of these, the Economics Department is considered the most important because of its cross-cutting involvement in practically all issue areas and the emphasis on economic issues within the OECD (Lehtonen, 2007; Lehtonen, 2009). The directorates work closely with the committee system (the committees and their subsidiary groups).

The OECD's division into sector-specific silos both within the Council and the Secretariat means there are divergent worldviews present within the OECD, especially compared to the IMF. The member state representatives in the committees, working parties and working groups often come from sector ministries (e.g. education, environment) that perceive the world through the worldview of these ministries.

\subsubsection{Worldview}

The different directorates of the OECD have distinct worldviews which correspond to those of their different governmental constituencies. Yet, they do not 
differ as much as national ministries but are influenced by the overarching worldview of the OECD Secretariat that emphasises the economic aspects and consequences of policy issues and instruments, and prioritises economic growth and development (Ruffing, 2010). Such a worldview is not surprising considering that the OECD is an institution for economic cooperation and development, and has been characterised as a focal point for the 'growth paradigm' prioritising economic growth as the first priority and yardstick for societies (Schmelzer, 2015). Yet, the overarching worldview means that the overarching normative emphasis on economic priorities and sector-specific priorities such as environmental protection sometimes conflict.

Regarding cognitive ideas, the overarching worldview defines economic instruments such as taxes, investment policies and deregulation as the most effective ones, and on a more fundamental level prioritises producing data that can be analysed econometrically, and highlights economic consequences (Lehtonen, 2009; Ruffing, 2010). There are differences over time as well as between directorates. In the 1970s, the overarching economic approach changed from a Keynesian emphasis on state intervention and planning to a neoclassical one emphasising free markets (Carroll and Kellow, 2011). In the Secretariat, the fragmentation or differences between directorates are also curtailed by cross-cutting expert groups as well as the recruitment process, which emphasises economic analytical skills and degrees in economics (Dostal, 2004).

\subsubsection{Membership and Decision-Making Procedures}

The OECD membership covers thirty-six of the richest countries (measured in GDP per capita) in the world. Notably, neither oil-producing rich countries from the Middle East nor some of the poorest EU countries (Bulgaria, Croatia, Malta and Romania) are members. New member states include countries such as Mexico, Chile and South Korea, which because of their status in 1992 as developing countries are not classified as developed countries in Annex I of the UNFCCC. Consequently, they are climate finance recipients rather than contributors and have more lenient mitigation obligations within the UNFCCC than the other OECD countries. Yet, the vast majority of the OECD member states are considered to be developed countries within the UNFCCC regime (with obligations to provide climate finance and to mitigate climate change). Altogether, while it still makes sense to speak about the OECD as the rich or developed countries' club, there is no full correspondence between being rich and developed and being an OECD member.

The processes of adopting output by the OECD member states vary but are generally characterised by a consensual nature. The formal OECD Council output 
consists of three types: output only binding on member states that vote for it (unless where otherwise specified), non-binding output (the most common kind) and output concerning the internal workings of the OECD (Carroll and Kellow, 2011). In other words, member states cannot be legally bound by decisions they do not wish to be bound by, but recommendations may rely on informal mechanisms of peer-pressure and reputational costs (Carroll and Kellow, 2011). Most of the preparatory work for and the negotiations concerning Council decisions take place within the committee system, and thus contested issues are generally solved or taken off the table before the Council discusses an issue. In the committee system, issues are decided unanimously by those who vote, meaning that a member state may choose to abstain without endorsing or blocking an issue (Carroll and Kellow, 2011).

\subsubsection{Autonomy}

The autonomy of the OECD Secretariat is somewhat limited. In terms of resources, the OECD is funded solely by member state contributions following a burdensharing key based on gross national product (GNP). The Council of Permanent Representatives negotiates and approves the annual budget. Consequently, the autonomy of the Secretariat is curtailed by its inability to engage in major activities that its principal does not approve of, and the risk of punishment should it contradict the preferences of several member states. Yet, the expert authority of the OECD Secretariat allows it to publish reviews and other analyses that are critical of member states. More importantly, the member states are closely involved in OECD decision-making. Secretariat staff drafts all OECD publications, which are subsequently subject to review in OECD committees, working parties and groups. The publications representing the opinion of the OECD as a whole require consensus-based approval by the member states, while those only representing the opinion of the OECD Secretariat only require approval from the Secretary-General. Yet even the publications not requiring member states' approval are subject to discussion in committees, working parties and groups, allowing states to raise criticism of the findings, but also allowing for the naming and shaming of member states in the committees. Because of the consensual nature of OECD decisionmaking, it is possible for OECD Secretariat's publications to go against the preferences of individual member states, but it is difficult to go against the preferences of most or even large groups of member states. As regards decisions not directly concerning specific publications, for example, which indicators to include in data collection, the member states generally also have substantial influence. 
Finally, the OECD mandate, as stipulated in the OECD Convention, is sufficiently broad to allow the OECD Secretariat to address any issue with relevance to economic growth, trade and stability (Carroll and Kellow, 2011), as long as the member states do not object.

\subsubsection{Interaction with Other Institutions}

The most important institution for the OECD is the International Energy Agency (IEA), which was established in 1974 by the OECD as a response to the 1973-4 oil crisis. The original purpose was to reduce dependence on imported oil, but it has gradually evolved to address all energy issues, including energy efficiency, renewable energy, coal and gas (Lesage and Van de Graaf, 2013; Van de Graaf and Colgan, 2016). The IEA is closely linked to the OECD both formally and informally through regular meetings between the officials from the two Paris-based Secretariats. Their membership circles are also largely coterminous, with OECD membership being a prerequisite for IEA membership and with only Chile, Colombia, Iceland, Israel and Slovenia as members of the OECD but not the IEA.

The OECD Secretariat often acts as a kind of secretariat to the G20, providing analyses of key issues, including taxation and climate change, for G20 working groups and ministerial meetings (Hajnal, 2019). The OECD also interacts with a wide range of specialised UN institutions in most areas except security (which the OECD does not address), including the UNFCCC, the United Nations Development Programme (UNDP), the World Health Organization and a range of other international institutions including several addressing environmental issues. Its role as a knowledge producing institution means it provides much of the data and information shaping the output of these institutions. The interaction between the OECD and $\mathrm{UN}$ institutions have at times been conflictive, since the OECD represents developed countries, whereas the UN institutions represent all countries in the world, a majority of which are developing. The OECD also cooperates with international economic institutions such as the IMF, the Bank of International Settlements (BIS) and the World Bank. Finally, the OECD's relationship with the EU ranges from the cooperative to the competitive, as the OECD covers most EU Member States and in certain areas (e.g. education statistics), the EU increasingly undertakes tasks similar to those of the OECD.

\subsubsection{Environmental Track Record}

OECD involvement in environmental issues dates further back than that of the G20 and the IMF. The OECD Environmental Policy Committee was established in 1970 
and the Environment Directorate in 1971 and particularly the latter has played an important role in developing environmental policy both at the global level and in OECD countries by producing knowledge about environmental issues. Thus, the OECD Environment Directorate has for more than four decades been at the forefront of crafting environmental policy solutions (Bernstein, 2001). The formal OECD knowledge output on environmental issues can be divided into the informatory, conceptual and analytical (Busch, 2009: 76). The informatory output consists of publications about past, present and future environmental conditions and policies. The conceptual output develops indicators and methods for designing, assessing and testing environmental conditions and policies. Finally, the analytical output evaluates and reviews environmental policies, instruments and performances, including the regular Environmental Performance Reviews of individual member states, a cornerstone of OECD environmental policy (see also Lehtonen, 2007, 2009). The OECD has focused on a range of environmental and sustainability-related issues inter alia chemicals, waste, sustainable development and increasingly climate change.

In terms of consequences, the OECD has been important in preparing and thus shaping several multilateral environmental agreements, including the 1979 Convention on Long-Range Transboundary Air Pollution (LRTAP) and the 1989 Basel Convention on Transboundary Movements of Hazardous Waste and their Disposal (Carroll and Kellow, 2011).

From the start, the OECD has promoted the integration of economic and environmental policies (Ruffing, 2010). This promotion is evident in its development of the polluter pays principle as a way of internalising the environmental costs of production, and hence of addressing environmental issues in a way that is compatible with free markets and free trade (Bernstein, 2001). On a broader scale, the OECD has been crucial in developing the norm complex or paradigm of liberal environmentalism, which describes a normative compromise between environmental protection and economic growth, and which predicates international environmental protection on the promotion and maintenance of a liberal economic order (Bernstein, 2001). More specifically, the OECD reacted to the 1987 Report of the World Commission on Environment and Development 'Our Common Future' (known as the Brundtland Report) as well as other calls in the 1980s for reconciling environmental protection with economic and social development in developing countries through the concept of sustainable development. The OECD reaction consisted of interpreting the Report's conclusions as support for market-based policy instruments to address environmental issues and for economic growth and environmental protection as being compatible (Bernstein, 2001). 
More recently, the OECD Secretariat's (OECD Secretariat, 2018) strategy for contributing to the implementation of the Paris Agreement included support for countries' low-emissions, climate-resilient pathways and for effective carbon prices, fossil fuel subsidy reform and making finance flows consistent with the Paris Agreement.

\subsection{The IMF}

The IMF was founded in 1944 at the ski resort Bretton Woods, New Hampshire by a group of Allied and neutral countries to ensure the stability of the international monetary system. Its sister organisation, the World Bank, ${ }^{4}$ was also established with the purpose of promoting economic development. Together, the IMF and the World Bank are commonly referred to as the Bretton Woods institutions. Although the Bretton Woods institutions are formally UN specialised agencies, they differ from other UN institutions in that they allocate voting rights based on GDP, and for this reason and because of their independence vis-à-vis the UN set-up they are commonly referred to as non-UN institutions. After the 1971 collapse of the Bretton Woods financial system of pegged but adjustable exchange rates, which the IMF was supposed to maintain, it increasingly focused on providing support to countries incurring fiscal problems and on developing countries (Momani and Hibben, 2018). Following the 1997-8 Asian financial crisis, the IMF faced increased criticism regarding the usefulness of its conditionalities and the Washington Consensus (see discussion in Section 3.3.3) and its role within global economic governance decreased. Yet, following the 2008-9 economic and financial crisis, the IMF returned to its former position of strength, as evident in its central role in addressing the sovereign debt crises in Europe (Joyce, 2013).

\subsubsection{Governance Functions}

The IMF's two most fundamental tasks are monitoring the economies of member states, especially their exchange rates and balance of payments, and acting as an international lender (Vreeland, 2007). Monitoring can be characterised as regulatory, and to some degree as knowledge output, and includes the so-called Article IV consultations it conducts with nearly all countries. These consultations focus on whether a country's currency is overvalued and its exchange rate policy appropriate, and increasingly also other economic policies. Lending, which can be

\footnotetext{
4 I use the term 'World Bank' to refer to the International Bank for Reconstruction and Development (established at Bretton Woods) and the International Development Association (established in 1956). The term the 'World Bank Group' is used to refer to the World Bank as well as the International Finance Corporation, the International Center for the Settlement of Investment Disputes and the Multilateral Investment Guarantee Agency.
} 
characterised as distributive output, takes place in countries facing a balance of payments crisis. IMF loans are dependent on a set of policy conditions that the country has to meet to receive the funds. These conditions include policy changes that will improve fiscal balances, typically in the shape of austerity policies (Ban and Gallagher, 2015; Kentikelenis et al., 2016). In practical terms, officials from the IMF and the government (typically from a finance ministry and central bank) draft a 'Letter of Intent' specifying what the country aims to do if it receives IMF lending. This letter is subsequently sent from the country's head of state or government to the IMF, and thereafter approved by the IMF Executive Board (Vreeland, 2007). The conditionalities take the shape of an IMF programme. In the case of developing countries, these programmes are often developed in collaboration with the World Bank. The IMF has faced considerable criticism regarding these programmes and the policy conditions for having a negative impact on the poor and for infringing on national sovereignty. While the former line of criticism is directed at the so-called 'Washington Consensus' (discussed in detail in Section 3.3.3) and its focus on economic liberalisation and austerity, the latter line of criticism concerns the power of the IMF vis-à-vis national governments (Barnett and Finnemore, 2004).

Besides monitoring and lending, the IMF also provides informal output in the shape of technical and policy advice to governments (often in connection with monitoring and lending) and creates and disseminates knowledge in the shape of publications and workshops. The IMF's Research Department is particularly important in the latter respect. Thus, the Fund's output is mainly formal and to a lesser degree informal and focuses on the reallocation of resources and to a lesser but still important extent on knowledge production (see Section 2.1).

\subsubsection{Organisational Set-up}

The IMF as a whole is formally governed by the Board of Governors, consisting of one representative from each member state, with each having a different number of votes (see Section 3.3.4). The Board of Governors appoints twenty-four directors who constitute the Executive Board. The five members with the largest number of votes (the United States, Japan, Germany, France and the United Kingdom) each appoint a director, while the other member states elect the other directors, which usually represent larger groups of countries, for example, the Nordic-Baltic countries. The Board of Governors only meet annually, while the Executive Board meets several times each week and is more actively involved in the day-to-day operations of the Fund. The Executive Board also appoints the managing director, who heads the IMF bureaucracy, and always comes from Europe (owing to a compromise according to which the World Bank president always comes from the United 
States). The IMF bureaucracy is organised into different departments, including the Area Departments covering different regions of the world, the Functional Departments and the Information, Liaison and Support Departments. The Functional Departments include departments undertaking cross-cutting functions, such as the Fiscal Affairs Department and the Research Department.

\subsubsection{Worldview}

During the period from its foundation until the late 1970s, Keynesianism and its emphasis on state intervention was the main theoretical foundation of IMF policy (Momani and Hibben, 2018). From the 1980s onwards, the IMF was a stronghold of the 'Washington Consensus', a paradigm based on monetarist economic policy (Chwieroth, 2008). This consensus can be understood as a policy paradigm rooted in the IMF, the World Bank, the Inter-American Development Bank, the US Executive, some members of the US Congress and Washington-based economic think tanks (Babb, 2013). The Washington Consensus emphasised structural reform such as privatisation; trade, financial and labour market liberalisation; and the protection of private property rights; as well as the IMF's traditional focus on cutting fiscal deficits (Babb, 2013). The use of policy conditionalities constituted a key component of the Consensus. In terms of economic theory, the Washington Consensus was rooted in monetarism and so-called 'new classical economics', which both drew on neoclassical economics and defined the market as providing the optimal solution and called for rolling back the role of the state (Momani and Hibben, 2018).

Yet, in the period following the 1997-8 Asian financial crisis, the IMF and the World Bank gradually changed their approach (Park and Vetterlein, 2010b), a change that was reinforced following the 2008-9 economic and financial crisis (Ban and Gallagher, 2015; Moschella, 2015). According to some spectators, the current IMF approach is best understood as a 'post-Washington Consensus' that is more open to Keynesian fiscal policies and less focused on cognitive ideas of liberalisation as creating growth and more emphasis on poverty reduction as a normative objective (Hibben, 2015). Importantly, the IMF's mandate was updated in 2012 to include all macroeconomic and financial sector issues that bear on global stability, and its objectives now is to 'foster global monetary cooperation, secure financial stability, facilitate international trade, promote high employment and sustainable economic growth, and reduce poverty around the world' (IMF, 2020b). How radical the changes in the approach of the IMF have been is debatable (Broome, 2015; Kentikelenis et al., 2016). The Fund has experienced radical change to 'its views on capital controls, the reorganisation of its financial 
surveillance function, its interventions in the austerity versus stimulus debate, and lastly, the Fund's views of state-creditor relations' (Ban and Gallagher, 2015, 132). Importantly, a change to so-called revisionist macroeconomic fiscal policy (which breaks with monetarist policy in advocating counter-cyclical fiscal spending) within the Fund was possible because revisionist policy proposals were framed in mainstream academic terms, for example, by relying on macroeconomic modelling (Ban, 2015). Yet, changes in other policy areas have been more incremental. Generally, the Fund narrowed the scope of its policy interventions to focus less on sweeping structural reform, while maintaining its core focus on fiscal consolidation (Broome, 2015). Thus, the Fund focused less on macroeconomic dynamics but kept fiscal balances as a core objective and continued to adhere to the cognitive idea of such consolidation as leading to economic stability and long-term growth. Furthermore, the changes do not imply a break with normative ideas defining maximising economic welfare as the key objective and free markets as the optimal instrument to achieve this. Although other objectives such as social inequality, gender and climate change were added, they were framed in economic terms as being important due to their impact on economic growth and stability (Clift and Robles, 2020; IMF, 2015b).

The constructivist literature on IOs has placed a great deal of emphasis on explaining the IMF approach - be it in terms of a Washington Consensus or a postWashington one - in terms of the IMF bureaucracy (Barnett and Finnemore, 2004; Chwieroth, 2008; Chwieroth, 2010). These explanations cover norm entrepreneurs as well as the worldview of the IMF (Barnett and Finnemore, 2004' Chwieroth, 2008, 2010; Hibben, 2015; Moschella, 2015). The bureaucratic worldview has generally been described based on the normative idea of maximising (economic) welfare, and cognitive ideas defining interventions in the market (e.g. regulation) as hindering the efficiency that is key to maximising welfare (Chwieroth, 2010). Key to this worldview is the economic training of the IMF officials, which traditionally hold a $\mathrm{PhD}$ in economics from a leading university, typically in the Anglo-Saxon world (Barnett and Finnemore, 2004; Chwieroth, 2010). Yet, the IMF worldview is not a fixed or homogenous entity (Kaya and Reay, 2019). As mentioned earlier, Keynesian ideas stressing a more active role for the state were prevalent until the late 1970s, and to some degree influenced IMF policy trends following the 2008-9 economic and financial crisis (Momani and Hibben, 2018). Nonetheless, even after Keynesianism's partial comeback in IMF policymaking, neoclassical economics continue to be at least as important in shaping IMF policy (Hibben, 2016; Momani and Hibben, 2018). Furthermore, much of the change in IMF policy has concerned changes to cognitive ideas regarding the causal effects of expansionary fiscal policy rather than fundamental beliefs about the effectiveness of markets, and has to 
a larger degree been driven by IMF top management than by an ideational change among IMF staff (Ban, 2015). Beyond changes over time, there are considerable differences between departments, with some departments, notably the Fiscal Affairs Department, being more informed by neoclassical economics (Ban, 2015; Park and Vetterlein, 2010b).

\subsubsection{Membership and Decision-Making Procedures}

At the time of writing, the IMF has 189 members, virtually all the countries in the world minus a few of the smallest countries (e.g. Liechtenstein, Tuvalu) as well as North Korea and Cuba for ideological reasons. Yet only 5 per cent of the votes are distributed equally, with the remainder distributed according to the size of their capital deposit or 'quota'. Each country's quota is determined by its economy, more specifically a combination of its GDP, current account transactions and the variability of these transactions over time as well as its official reserves (IMF, 2008c, 2017b). Consequently, the United States has the largest vote share (17 per cent of the total votes), followed by Japan, China, Germany, the United Kingdom and France with 4-6 per cent each (IMF, 2020c). The G7 as a bloc controls 41 per cent of the votes. Most decisions are reached by a simple majority of 50 per cent of the votes, but some require an 85 per cent supermajority. Yet, member states rarely vote, instead generally reaching decisions via consensus (Vreeland, 2007). What this means in terms of the influence of individual member states is debatable. Some scholars have argued that the influence of the United States greatly exceeds its share of the votes, inter alia because smaller member states fear antagonising it (Broz and Hawes, 2006; Stone, 2008). On a related note, Grigoire Pop-Eleches (2009) argues that the member states with the largest economies (including but not limited to the United States) de facto define the course for the IMF. All things considered, while the United States and other major member states are undisputedly very powerful among the member states, especially regarding discussions on the Executive Board, their degree of influence is often dependent on the context and likely to be greater, the more closely involved the Board is (Momani, 2007).

\subsubsection{Autonomy}

The IMF bureaucracy enjoys considerable autonomy from its member states, especially when compared to the OECD. This autonomy is based on its control over its own resources, the limited involvement of member states in the decisionmaking process, and its broad mandate. Regarding resources, each member state 
has a 'capital subscription' similar to a deposit in a bank account with the IMF. It is these funds that the IMF lends out. The interest rate on the loans and the profits from investing funds subsequently pays for the activities of the Fund. Hence, the IMF bureaucracy's activities are not dependent on which activities its member states decide to fund (Barnett and Finnemore, 2004). For most other IOs, the funding of their activities come from member state donations, and consequently the member states may either collectively decide whether to fund a given activity or not, or a member state may individually decide to withhold funding if it does not approve of the IO's policies (Graham and Serdaru, 2020).

As regards decision-making, the Executive Board approves all transfers of Fund resources to member states (especially lending), staff reports on member states, changes to member state deposits (so-called quotas) and most other major actions by the Fund (Barnett and Finnemore, 2004). Yet, publications on more general topics and of a more scientific kind (e.g. on the global costs of fossil fuel subsidies) as well as more low-key policy advice do not require Board approval. This is important, as the IMF is a large organisation covering a range of topics and virtually all countries, and although the Executive Board meets several times a week, it does not have the time to go into detail regarding all IMF activities, but instead focuses on the most important ones. The IMF staff draft all proposals that the Board discusses and decides. Although Board members on a few, politically important occasions have been involved in drafting lending programmes, and the IMF bureaucracy avoids drafting proposals that Executive Directors object to, the IMF bureaucracy has considerable discretion, especially concerning lower profile issues (Barnett and Finnemore, 2004; Momani, 2007). Not only may they define how policy issues are framed and which options are on the table, they also shape the agenda of the IMF generally and the Board specifically, and may place new items on this agenda or keep issues off it. Member states without a seat on the Executive Board have a very limited say in the activities of the IMF.

Finally, the IMF mandate both in its post and pre-2012 incarnations concerns economic policymaking without clearly demarcating its boundaries. Given that economic policymaking has profound implications for other policy areas, particularly but not limited to how fiscal policy determines the funding allocated to policy areas, the IMF staff has discretion to address all areas of domestic policy. This discretion is something the IMF staff arrived at during the 1970s, 1980s and 1990s by broadening its scope from focusing on currency exchange rates to practically all policy areas with economic implications, an expansion that relied on the argument that these policies and the fiscal deficit had a significant impact on exchange rates (Barnett and Finnemore, 2004, chapter 3). 


\subsubsection{Interaction with Other Institutions}

The IMF's closest partner among the international institutions is the World Bank. Together they are referred to as the Bretton Woods institutions, and their headquarters are next to each other in Washington, DC. More importantly, they share a common policy paradigm in the Washington Consensus (as well as its more recent incarnations), and both moved in the same direction after this paradigm was transformed (Babb, 2013; Park and Vetterlein, 2010b). On an even more fundamental level, their bureaucracies share similar economic worldviews emphasising economic growth and stability as normative objectives and adhering to cognitive ideas defining free markets as causing such growth. Their relationships with their principals are also similar in terms of membership circle and degree of autonomy. Finally, the two Bretton Woods institutions often collaborate closely 'on the ground' in developing countries, both in terms of policy conditionalities in the context of lending and in terms of more general policy advice (Kranke, 2020; Momani and Hibben, 2015). Often there is a division of labour, in which the IMF focuses on macroeconomic and fiscal issues and the World Bank on development issues and concrete projects. While IMF collaboration with the World Bank mainly concerns developing countries (which the World Bank's jurisdiction is limited to), it has also collaborated closely with the European Union (EU) in the context of the debt crises of European countries such as Greece.

Beyond the World Bank and the EU, the Fund also collaborates with regional Multilateral Development Banks, especially within countries. The Washingtonbased Inter-American Development Bank in particular has also been considered a stronghold of the Washington Consensus (Babb, 2013). Other economic institutions including the OECD (Lesage and Van de Graaf, 2013) collaborate with the IMF on producing and disseminating knowledge. Likewise, the Fund has provided analyses to the G20 on a range of issues, mainly concerning economic policy coordination.

\subsubsection{Environmental Track Record}

Traditionally, the IMF has not paid much attention to environmental issues, and when it has done so, its approach has clearly reflected its economic worldview. From 1990 onwards, the Executive Board has induced it to address environmental issues, which has led to IMF staff defining environmental degradation as a potential threat to trade and budget balances as well as economic growth (Gandhi, 1998). IMF staff integrated environmental concerns in their interaction with states, including IMF programmes, mainly focusing on win-win situations such as phasing out subsidies to chemicals (Lindenthal and Koch, 2013). The staff also stressed 
Pigouvian taxes (and to some degree also reform of environmentally harmful subsidies) as the optimal solution to environmental degradation (Gandhi and McMorran, 1996). Yet, this did not lead to substantial changes to Fund policy (Lindenthal and Koch, 2013); rather, IMF staff were keen on stressing that other institutions, especially the World Bank, were more suitable in terms of expertise and a mandate to address the issue (Fischer, 1996). In 2001, the IMF set up an environmental team within its Fiscal Affairs Department to support the integration of environmental concerns in IMF interaction with states (IMF Survey, 2001). Since 2001, the IMF has increasingly focused on climate change, including its macroeconomic impact, fossil fuel subsidies and carbon pricing (Lindenthal and Koch, 2013). The Fund has recently defined the key areas in which it is addressing climate change as (1) supporting countries contemplating carbon pricing and fossil fuel subsidy reform as a means of meeting commitments under the Paris Agreement, (2) supporting vulnerable developing countries build resilience to climate change, and (3) collaborating with other institutions on improving climaterelated regulation of finance and insurance (IMF, 2019g, 2019h).

Nonetheless, the Fund has continuously been criticised for the negative environmental consequences of its policy conditionalities and advice. This criticism has focused on its advice and conditionalities inducing (especially heavily indebted) countries to commercially exploit natural resources, including rain forests and mineral resources, and to cut expenditure on environmental protection (Harvey, 2005; Le Prestre, 1989; Shandra et al., 2011). On a more fundamental level, the Fund has been criticised for its role in promoting the Washington Consensus that has led to less interventionist, more market-based policies and in general to a globalised economy in which emissions-intensive industries have moved to developing countries (Paterson and P-Laberge, 2018).

\subsection{Summary}

This chapter has outlined the differences and similarities between the three institutions that may be relevant for how they have addressed the two issues. Most fundamentally, the institutions differ in the governance functions with the G20 as a political forum for discussion and steering national policies, the OECD is a knowledge provider and the IMF is an operational institution carrying out its own policies. The organisational structure of the three institutions also varies considerably, with the IMF and the OECD having bureaucracies, and the G20 being a forum. Furthermore, the IMF bureaucracy has considerably more autonomy than the OECD's. They also differ in terms of membership, with the G20 covering twenty of the world's largest economies, the OECD all developed countries and the 
IMF virtually all countries. In relation to this, the G20 and the OECD use consensus-based procedures to reach agreement and the IMF's voting procedures are based on countries' financial contributions. Finally, the OECD has a more extensive track record regarding environmental issues than the other two institutions.

In terms of similarities, all three share a worldview that focuses on the economic aspects of problems and defines economic growth and stability as key issues, but where the IMF is more strictly focused on economic objectives. The institutions also interact to a large degree with a similar set of institutions, including each other and the World Bank, while relations with the UN institutions are sometimes conflictual. All of these factors are relevant for how the economic institutions have addressed the two issues as economic issues, that is, economisation. How these differences and similarities play out with regard to the way the institutions address fossil fuel subsidies and climate finance is the topic of the remainder of this book. 